\title{
Gender as a Moderator of the Association Between Exposure to Violent Media Contents and Aggressive Behaviour in a Sample of Nigerian In-School Adolescents
}

\author{
Chinyere Augusta Nwajiuba ${ }^{1}$, Chiedu Eseadi ${ }^{2}$, Paul N. Onwuasoanya ${ }^{2}$, Emenike N. Anyaegbunam ${ }^{3}$, \\ Oluchi Queen Onwudinjo ${ }^{1}$, Rowland C. Uwakwe ${ }^{1}$, Ngozi Awoke ${ }^{1}$, Ijeoma Awa Kalu ${ }^{1}$, Iheanacho Christian \\ Agboti $^{3}$, Kay C. Onyechi ${ }^{2} \&$ Bartholomew C. Nwefuru ${ }^{2}$ \\ ${ }^{1}$ Faculty of Education, Alex Ekwueme Federal University Ndufu-Alike Ikwo, Ebonyi State, Nigeria \\ ${ }^{2}$ Faculty of Education, University of Nigeria Nsukka, Enugu State, Nigeria \\ ${ }^{3}$ Faculty of Management and Social Sciences, Alex Ekwueme Federal University Ndufu-Alike Ikwo, Ebonyi State, \\ Nigeria \\ Correspondence: Eseadi Chiedu, Faculty of Education, University of Nigeria Nsukka, P.M.B. 410001, Enugu \\ State, Nigeria. E-mail: chiedu.eseadi@unn.edu.ng
}

Received: August 20, 2019 Accepted: October 20, 2019 Online Published: November 4, 2019

doi:10.5539/gjhs.v11n14p10 URL: https://doi.org/10.5539/gjhs.v11n14p10

\begin{abstract}
This is a correlational survey research which was carried out to find out if gender is a moderator of the association between exposure to violent media contents and aggressive behaviour in a sample of Nigerian in-school adolescents. The respondents were 603 senior secondary class 2 adolescents in Onitsha Education Zone of Anambra State. Two self-report questionnaires measuring violent media contents consumption and aggressive behaviour respectively were used for collection of data. Chart, partial correlation, and regression statistics were utlized to analyze and interpret the data. The research hypothesis was considered significant at .05 probability level. Results indicate that, to a very high extent, gender moderated the relationship between exposure to violent media contents and aggressive behaviour among in-school adolescents. Also, it was found that gender significantly moderated the relationship between exposure to violent media contents and aggressive behaviour among in-school adolescents. It is recommended that Nigerian secondary schools should initiate and promote gender-friendly and gender-transformative school-based interventions that would help mitigate aggression among in-school adolescents.
\end{abstract}

Keywords: gender, violent media contents, aggressive behaviour, in-school adolescents

\section{Introduction}

Gender determines our perception of men and women and the way they are expected to reason and behave. Gender determines what is expected, allowed and valued in a woman or a man in a given context (Mediterranean Institute of Gender Studies, 2005; Office of the Special Advisor on Gender Issues and Advancement of Women, 2001). Kirsh and Olczak (2002) observed that gender could influence the relationship between violent media contents consumption and aggressive behaviour. Exposure to violent media contents has been considered a significant contributory risk factor for increased aggression (Bushman \& Anderson, 2015). Among Nigerian in-school adolescents, aggressive behaviour is often displayed through bullying, knife attack, arson, and peer victimization (Adefunke, 2010; Aluede 2011; Obikeze \& Obi, 2015). The fact that violent media contents consumption seem to be an everyday issue for the Nigerian in-school adolescents necessitated this study.

Studies indicated that several violent media contents seem to dominate the Nigerian entertainment markets making them easily accessible to in-school adolescents (Eseadi, 2016; Onuigbo, Eseadi, Onwuasoanya, \& Eze, 2019). Of more concern is that there is dearth of government policy in Nigeria regarding violent media contents distribution and consumption which could help to curtail access to them. Results from previous studies points to the fact that early life exposure to violent media contents could be predictive of violent behaviours at adulthood stage of life compared to a scenario in which individuals were not exposed to such contents (Eseadi, 2016; Huesmann, Moise-Titus, Podolski \& Eron, 2003). Some in-school adolescents could be more vulnerable to the potential negative effects of consuming violent media contents than others (Onuigbo, Eseadi, Onwuasoanya, \& Eze, 2019). 
Considering the length of exposure, psychological issues, such as, traumatic stress, anxiety, depression, substance use, antisocial behaviours, and academic difficulties may ensue among adolescents who consume so much of violent media contents (Eseadi, 2016). According to Onuigbo, Eseadi, Onwuasoanya and Eze (2019), there are still lessons to learn from investigating the moderating effect of gender in the association between violent media consumption and aggression. To this end, the objective of this study was to find out if gender is a moderator of the association between exposure to violent media contents and aggressive behaviour in a sample of Nigerian in-school adolescents.

\subsection{Research Question}

To what extent does gender moderate the relationship between exposure to violent media contents and aggressive behaviour among in-school adolescents?

\subsection{Hypothesis}

Gender will not significantly moderate the relationship between exposure to violent media contents and aggressive behaviour among in-school adolescents.

\section{Method}

This research is a correlational survey which was carried out among in-school adolescents in Onitsha Education Zone of Anambra State, Nigeria. Out of a population of 34472 in-school adolescents, the study respondents were 603 senior secondary class 2 adolescents obtained through multi-stage sampling procedure. Participating students gave their informed assent. In carrying out this investigation, the American Psychological Association's research principles were put into consideration. The Violent Media Contents Questionnaire (VMCQ, Cronbach's $\alpha=0.88$ ) and the In-School Adolescents' Aggressive Behaviour Questionnaire (IAABQ, Cronbach's $\alpha=0.83$ ) by Eseadi (2016) were used for collection of data. The research purposes were explained to the participating students before they completed the questionnaires on the spot with the help of a research assistant. To analyze and interpret the data, chart, partial correlation and regression statistics were used. The research hypothesis was tested at 0.05 significant level. Computer software utilized for statistical data processing and analysis was the Statistical Package for the Social Sciences (SPSS), version 22.

\section{Results}

Research Question: To what extent does gender moderate the relationship between exposure to violent media contents and aggressive behaviour among in-school adolescents?

Table 1. Partial correlation analysis showing the extent to which gender moderate the relationship between exposure to violent media contents and aggressive behaviour among in-school adolescents

\begin{tabular}{|c|c|c|c|c|c|}
\hline Variables & Gender & $\mathbf{N}$ & SD & $\mathbf{r}_{p}$ & Decision \\
\hline \multirow[t]{3}{*}{ Violent Media Contents } & Male & 348 & $3.26 \pm .29$ & & \\
\hline & Female & 255 & $3.24 \pm .28$ & & \\
\hline & Total & 603 & $3.25 \pm .29$ & 0.82 & Very High Exten \\
\hline \multirow[t]{3}{*}{ Aggressive Behaviour } & Male & 348 & $3.38 \pm .37$ & & \\
\hline & Female & 255 & $3.37 \pm .36$ & & \\
\hline & Total & 603 & $3.37 \pm .36$ & & \\
\hline
\end{tabular}

$\mathrm{N}=$ number of respondents, $\mathrm{r}_{\mathbf{p}}=$ Partial correlation coefficient.

Results in Table 1 revealed that based on gender, the mean exposure to violent media contents was 3.26 with standard deviation of 0.29 for the male in-school adolescents while mean exposure of 3.24 with standard deviation of 0.28 was obtained for the female in-school adolescents; and the overall mean exposure was 3.25 with standard deviation of 0.29. As shown in the table, the mean exposure for the male in-school adolescents on aggressive behaviour was 3.38 with standard deviation of 0.37 ; while the mean exposure for the female in-school adolescents on aggressive behaviour was 3.37 with standard deviation of 0.36 ; and the overall mean exposure was 3.37 with standard deviation of 0.36 . The value of the partial correlation coefficient $\left(\mathrm{r}_{p}\right)$ which is 0.82 indicates that the extent to which gender moderate the relationship between exposure to violent media contents and aggressive behaviour among in-school adolescents is very high. 


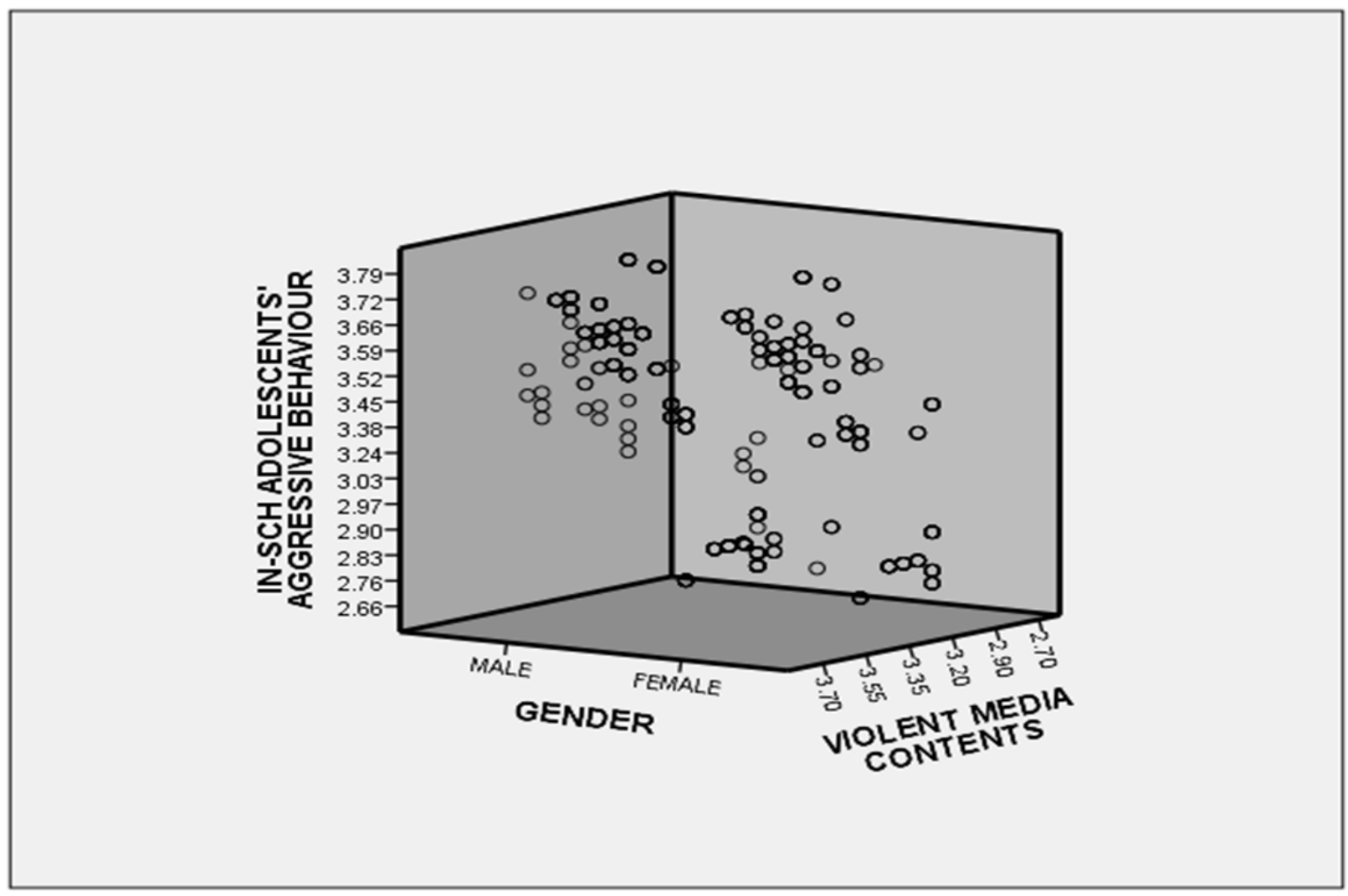

Figure 1. Chart showing gender as a moderator in the relationship between exposure to violent media contents and aggressive behaviour among in-school adolescents

Figure 1 is a chart showing how gender moderates the relationship between violent media contents and aggressive behaviour among in-school adolescents. The figure confirms that the relationship between exposure to violent media contents and aggressive behaviour is being moderated by gender to a very high extent.

Hypothesis: Gender will not significantly moderate the relationship between viewing violent media contents and aggressive behaviour among in-school adolescents.

Table 2. Summary of regression analysis showing gender as a moderator of the relationship between exposure to violent media contents and aggressive behaviour among in-school adolescents

\begin{tabular}{lllllll}
\hline Variables & $\mathbf{N}$ & $\mathbf{F}$ & $\mathbf{R}^{2}$ & $\mathbf{B}$ & Sig. & Decision \\
\hline Violent Media Contents & & & & & & Rejected \\
Gender & 603 & 615.84 & .672 & .820 & .000 & \\
Aggressive Behaviour & & & & & & \\
\hline
\end{tabular}

Results in Table 2 revealed that gender significantly moderated the relationship between exposure to violent media contents and aggressive behaviour among in-school adolescents, $R^{2}=.67, F(1,602)=615.84, \beta=.82, p<.05$. The $\mathrm{R}^{2}$ value of .67 shows that violent media contents accounts for $67 \%$ of the variance in aggressive behaviour when moderated by gender.

\section{Discussion}

The purpose of this study was to find out if gender is a moderator of the relationship between violent media contents exposure and aggressive behaviour in a sample of Nigerian in-school adolescents. The study demonstrated that, to a very high extent, gender moderated the relationship between violent media contents exposure and aggressive behaviour among in-school adolescents. Also, it was found that gender significantly moderated the relationship between violent media contents exposure and aggressive behaviour among in-school 
adolescents. Kirsh and Olczak (2002) reported that gender could influence the association between violent media contents consumption and aggression. Krahe, Busching and Möller (2012) reported that violent media contents had larger effect on females compared to their male counterparts; the consumption of violent media is linked to desensitization in females to the extent that they could consider violence as a normal thing, thereby making them vulnerable to aggression. Tarabah, Badr, Usta and Doyle (2016) revealed that gender is a moderator in the association between violent media contents consumption and aggression. Kirsh, Mounts and Olczak (2006) reported that gender could bring about variations in violent media content consumption. However, our finding is inconsistent with recent result by Onuigbo, Eseadi, Onwuasoanya and Eze (2019) which showed that gender is not a significant moderator in the correlation between violent media contents consumption and aggressive behaviour of adolescent students. The disparity could be due to the data analysis approach employed. The implications of the present findings cannot be overstated. A good number of professional counsellors should be employed and older counsellors should be retrained through in-service training programmes, capacity building workshops and refresher courses on media education and emerging violence prevention approaches. Finally, it is recommended that Nigerian secondary schools should initiate and promote gender-friendly and gender-transformative school-based interventions that would help mitigate aggression among in-school adolescents.

\section{Conclusion}

The study concludes that to a very high extent, gender moderated the relationship between exposure to violent media contents and aggressive behaviour of in-school adolescents. Gender significantly moderated the relationship between exposure to violent media contents and aggressive behaviour of in-school adolescents. Nigerian secondary schools should initiate and promote gender-friendly and gender-transformative school-based interventions that would help mitigate aggression among in-school adolescents.

\section{Note/Acknowledgements}

This article was drafted based on empirical data of a postgraduate research investigating the relationship of violent video games play and violent media contents with aggressive behaviour among adolescent students. The study sample size and research method are similar with other aspects of the work which are being considered for publication in this and other journals. We sincerely thank the adolescent students who took part in this survey.

\section{Competing Interests Statement}

The authors declare that there are no competing or potential conflicts of interest.

\section{References}

Adefunke, E. S. (2010). Types and prevalence of peer victimization among secondary schoolstudents in Osun State, Nigeria: implications for counselling. International Journal for Cross-Disciplinary Subjects in Education, 1(1), 53-60. https://doi.org/10.20533/ijcdse.2042.6364.2010.0008

Aluede, O. (2011). Managing bullying problems in Nigerian secondary schools: some counselling interventions for implementation. The African Symposium, 11(1), 138-145.

Bushman, B. J., \& Anderson, C. A. (2015). Understanding causality in the effects of media violence. American Behavioral Scientist, 59(14), 1807-1821. https://doi.org/10.1177/0002764215596554

Eseadi, C. (2016). Violent video games and violent media contents as correlates of aggressive behavior among in-school adolescents in Onitsha Education Zone of Anambra State, Nigeria (Postgraduate thesis, University of Nigeria Nsukka, Nigeria).

Huesmann, L. R., Moise-Titus, J., Podolski, C. L., \& Eron, L. D. (2003). Longitudinal relations between children's exposure to TV violence and their aggressive and violent behaviour in young adulthood: 1977-1992. Developmental Psychology, 39, 201-221. https://doi.org/10.1037/0012-1649.39.2.201

Kirsh, S. J., \& Olczak, P. V. (2002). The effects of extremely violent comic books on social information processing. Journal of Interpersonal Violence, 17(11), 1160-1178. https://doi.org/10.1177/088626002237400

Kirsh, S. J., Mounts, J. R. W., \& Olczak, P. V. (2006). Violent media consumption and the recognition of dynamic facial expressions. Journal of Interpersonal Violence, 21(5), 571-584. https://doi.org/10.1177/0886260506286840

Krahe, B., Busching, R., \& Möller, I. (2012). Media violence use and aggression among German adolescents: associations and trajectories of change in a three-wave longitudinal study. Psychology of Popular Media Culture, 1(3), 152-166. https://doi.org/10.1037/a0028663

Mediterranean Institute of Gender Studies. (2005). Glossary of gender-related terms. Retrieved August 29, 2015, 
from http://www.peacewomen.org/assets/file/AdvocacyEducationTools/genderglossarymigs_aug2005.pdf

Obikeze, N., \& Obi, I. (2015). Prevalence and incidence of aggressive behaviors among adolescents in senior secondary schools in Anambra State. Journal of Emerging Trends in Educational Research and Policy Studies, 6(2), 139-145.

Office of the Special Advisor on Gender Issues and Advancement of Women. (2001). Gender mainstreaming: strategy for promoting gender equality (revised). Retrieved August 29, 2015, from http://www.un.org/womenwatch/osagi/pdf/factsheet1.pdf

Onuigbo, L. N., Eseadi, C., Onwuasoanya, P. N., \& Eze, U. N. (2019). Violent Media Content Viewing and Aggressive Behavior in College Students in Nigeria: Moderating Effects of Gender and Parental Mediation. International Journal of u-and e-Service, Science and Technology, 12(2), 9-24.

Tarabah, A., Badr, L. K., Usta, J., \& Doyle, J. (2016). Exposure to violence and children's desensitization attitudes in Lebanon. Journal of Interpersonal Violence, 31(18), 3017-3038. https://doi.org/10.1177/0886260515584337

\section{Copyrights}

Copyright for this article is retained by the author(s), with first publication rights granted to the journal.

This is an open-access article distributed under the terms and conditions of the Creative Commons Attribution license (http://creativecommons.org/licenses/by/4.0/). 